\title{
PERTAUTAN EMOSI SEJARAH, MAGIS, \\ DAN PENJAGA MAZHAB: \\ ANALISIS TERHADAP MASJID AGUNG KYAI GEDE \\ DI KOTAWARINGIN BARAT, \\ KALIMANTAN TENGAH
}

\author{
Sulaiman \\ Dosen Tasawuf dan Psikoterapi, Fakultas Ushuluddin IAIN Walisongo \\ Dosen Pascasarjana IAIN Walisongo \\ Email: alkumayi97@yahoo.co.id
}

Abstrak: Masjid Kyai Gede adalah salah satu masjid peninggalan bersejarah di Kotawaringin Barat, Kalimantan Tengah. Dilihat dari bentuk arsitekturalnya, masjid ini mirip dengan Masjid Demak Jawa Tengah, yang mengindikasikan kuatnya pengaruh Demak di pedalaman Kalimantan. Selain itu, masjid ini juga mengandung aspek-aspek magis dan sekaligus penjaga mazhab ahlu al-sunnah wa al-jamâ'ah. Dalam tulisan ini, penulis akan menganalisis masjid ini dalam tiga fokus bahasan: pertautan sejarah, unsur magis, dan penjaga mazhab.

Kata Kunci: Kyai Gede, Masjid, ahlu al-sunnah wa al-jamâ'ah, Islâm, îmân, dan ihsân.

\section{A. Pendahuluan}

Dalam sejarah Islam, masjid telah memainkan peranan yang bervariasi dalam komunitas dan kebudayaan yang berbeda-beda, tetapi tidak pernah menjadi peranan sentral sebagaimana Gereja Kristen, setidak-tidaknya karena disebabkan oleh tidak adanya kependetaan (priesthood) dalam Islam dan karenanya tidak memberi ruang untuk sebuah masjid yang terlembagakan di bawah hierarki resmi. Atau, untuk memparafrase perbedaan ini, setiap Muslim baik laki-laki maupun perempuan adalah 'alim ulama' (priest) dan secara khusus menjalankan kewajiban-kewajiban yang sangat religious di rumah, sehingga dalam kenyataannya setiap rumah Muslim adalah masjid (Chittick dalam Mahmutæhajiæ, 2006: x), dan untuk bangunan masjid, mereka menyebutnya dengan 'rumah Allah.' Setiap Muslim di dunia sama-sama berhak menikmati 
fungsi masjid, sama-sama berhak memanfaatkan fasilitasnya. Tak ada izin atau pentahbisan, tak dipungut bayaran atau tak ada langganan, tak ada kuota, batas, atau larangan bagi siapa pun di masjid (al-Faruqi, 1986: 152). Fenomena ini digambarkan dengan sangat singkat oleh Talmon-Heller (2007: 31) sebagai "the mosque was unreservedly open to all" ("masjid jelas-jelas terbuka untuk semua").

Masjid khususnya masjid jami (masjid jâmi') atau masjid al-jum 'ah, selain merupakan tempat peribadatan, juga berfungsi sebagai pusat peradaban keagamaan; masjid menjadi titik fokus kehidupan keagamaan dan sosial. Dalam fungsi terakhir ini, masjid bagi kaum muslim menjadi pusat atau tempat mendapatkan pendidikan keagamaan, bimbingan moral, dan sosial; pusat penyelesaian masalah di antara jemaah; tempat melaksanakan perayaan atau acara yang berkaitan dengan daur kehidupan (life-cycle) seperti khitanan dan pernikahan; tempat menyelenggarakan komunikasi umum; pusat usaha penyantunan sosial; dan bahkan pusat mobilisasi politik (Azra, 2002, I: 342343). Bagi umat Islam, masjid merupakan tempat yang dianggap suci karena ia adalah tempat melakukan ibadah, terutama salat. Masjid bagi sekelompok orang ternyata tidak hanya mengandung dimensi tempat ibadah, sehingga perlu disucikan, akan tetapi juga mengandung makna kesakralan tertentu. Sebagai tempat sakral, masjid menjadi tempat ibadah, seperti salat wajib, salat Jumat, salat rawatib, iktikaf pada bulan Ramadan dan pengajian-pengajian keagamaan, selain itu juga menjadi suci karena didirikan oleh seorang yang dianggap wali (Syam, 2005: 117) atau karena tempat tersebut telah memberikan sesuatu yang dianggap 'penyelamat' dari berbagai bentuk musibah atau kejahatan (alKumayi, 2011). Selain itu, melalui masjid kita dapat mengkaji ada tidaknya unsur-unsur 'asing' kaitannya dengan 'kebudayaan Islam' (Pijper, 1985:14-15). Dengan kerangka berpikir seperti ini, maka kehadiran sebuah masjid di suatu tempat, khususnya yang bernilai sejarah (baca: masjid kuno), dapat direkonstruksi untuk mengetahui 'makna-makna' yang terkandung dalam bangunan dan segala jenis arsitektur yang menghiasi masjid (Handinoto dan Hartono, 2007; Machrus, 2008).

Dalam tulisan ini, penulis akan menganalisis Masjid Kyai Gede, yang terletak di desa Kotawaringin Hulu, Kecamatan Kotawaringin Lama, Kabupaten Kotawaringin Barat, Provinsi Kalimantan Tengah, yang dibangun pada tahun $1632 \mathrm{M}(1052 \mathrm{H})$, tepatnya pada masa pemerintahan Sultan Mustain Billah (1650-1678 M), raja keempat dari Kesultanan Banjarmasin. Nama Masjid Kyai Gede diambil dari nama seorang ulama yang telah berjasa besar dalam menyebarkan ajaran Islam di Pulau Kalimantan, khususnya di wilayah Kotawaringin. 
Ulama tersebut adalah Kyai Gede, seorang ulama asal Jawa yang diutus oleh Kesultanan Demak untuk menyebarkan ajaran Islam di Pulau Kalimantan. Kedatangan Kyai Gede tersebut disambut baik oleh Sultan Mustain Billah. Oleh sang Sultan, Kyai Gede kemudian ditugaskan menyebarkan Islam di wilayah Kotawaringin, sekaligus membawa misi untuk merintis kesultanan baru di wilayah ini. Berkat jasa-jasanya yang besar dalam menyebarkan Islam dan membangun wilayah Kotawaringin, Sultan Mustainubillah kemudian menganugerahi jabatan kepada Kyai Gede sebagai Adipati di Kotawaringin dengan pangkat Patih Hamengkubumi dan bergelar Adipati Gede Ing Kotawaringin. Namun, hadiah yang paling berharga dari sang Sultan bagi Kyai Gede adalah dibangunnya sebuah masjid yang kelak bukan sekedar sebagai tempat beribadah, melainkan juga sebagai pusat kegiatan-kegiatan kemasyarakatan bagi Kyai Gede dan para pengikutnya. Bersama para pengikutnya, yang waktu itu hanya berjumlah 40 orang, Kyai Gede kemudian membangun Kotawaringin dari hutan belantara menjadi sebuah kawasan permukiman yang cukup maju. Kalaupun wilayah Kotawaringin sekarang ini menjadi salah satu kota yang terbilang maju di Kalimantan, hal itu tidak dapat dipisahkan dari jasa besar Kyai Gede dan para pengikutnya (http://id.wikipedia. org/).

Berdasarkan uraian di atas, analisis terhadap masjid ini difokuskan pada tiga aspek: pertautan sejarah, magis, dan penjaga mazhab. Ketiga aspek ini merupakan ciri spesifik yang menjadikan masjid ini layak dianalisis secara akademik.

\section{B. Pertautan Sejarah: Arsitektur Masjid Kyai Gede}

Menurut Kuntowijoyo (2003), masjid berfungsi sebagai pusat budaya dan kehidupan umat Islam. Sebagai produk budaya, arsitektur masjid pada dasarnya dipengaruhi oleh faktor-faktor lingkungan, faktor budaya, dan teknologi. Faktor lingkungan, mencakup kondisi alamiah lingkungan seperti faktor geografis, geologis, iklim, suhu, dan sebagainya. Faktor teknologi, meliputi aspek pengelolaan sumber daya dan ketrampilan teknis membangun (Iskandar, 2004). Mengikuti pendapat Suparlan (1993: 107; 1995: 111), bahwa kebudayaan itu merupakan keseluruhan pengetahuan yang dipunyai oleh manusia sebagai makhluk sosial, yang isinya adalah perangkat-perangkat, model-model pengetahuan yang secara selektif dapat digunakan untuk memahami dan menginterpretasikan lingkungan yang dihadapi dan untuk mendorong dan menciptakan tindakan-tindakan yang diperlukannya. Maka, arsitektur bangunan masjid adalah bagian dari produk budaya yang merupakan manifestasi dari pengetahuan dan interpretasi umat Islam terhadap ajaran Islam. 
Dari segi perubahan bentuk arsitektur, ada dua hal yang pantas ditelaah, yaitu transformasi bentuk serta transformasi ruang arsitektur masjid. Ini merupakan dua hal yang berkaitan, karena figurasi bentuk dilahirkan dari pembatas ruang melalui pola, hirarki, dan organisasi ruang itu sendiri. Dalam kaitan itu, akibat persinggungan budaya lokal dengan budaya asing di bumi nusantara selama ini serta proses tawar-menawar dan tukar menukar elemenelemen budaya yang dimiliki, terjadilah akulturasi desain (Iskandar, 2004).

Karya arsitektur selalu mengandung pesan di dalamnya, baik berupa gagasan, ideologi bahkan misi yang ingin dicapai oleh sang arsitek melalui hasil karyanya tersebut. Pesan ini biasanya terbentuk dari elemen-elemen arsitektural bangunannya, baik yang lepas maupun yang terkait sehingga membentuk suatu sistem tanda baik eksterior maupun interior. Sejumlah masjid yang dibangun di berbagai daerah senantiasa menonjolkan unsur-unsur daerah dengan nilai tradisionalnya. Oleh karena itu keterkaitan dengan budaya lokal biasanya sangat kuat, masjid dapat bertahan dalam kurun waktu yang lama, sehingga dalam perkembangannya masjid selalu identik dengan kultur daerah di sekitarnya (Bennyarmansyah, 2011). Untuk mengaji ada tidaknya unsurunsur 'asing' kaitannya dengan 'kebudayaan Islam' biasanya yang dijadikan ukuran/acuan pertama adalah mesjid (Pijper, 1985: 14-15).

Menurut Kahera (2002: 5-6), tidak ada tradisi bangunan yang bebas kebudayaan, dan tradisi-tradisi bangunan sebagian besar merupakan bagian dari warisan budaya sebagaimana pakaian, makanan, musik, dan bahasa. Apa yang dianggap initial (yang pertama) tetaplah sudah terpengaruh dan interkoneksi dengan lingkungan sosial dan budaya lain. Layaknya sejarah, maka bentuk bangunan adalah sesuatu yang diciptakan, diciptakan kembali, dan dimodeli kembali. Karena itu, tegas Kahera (2002: 6), “Tidak ada arsitektur tanpa aturan-aturan konstruksi yang tak dapat dilanggar dan interpretasi yang dibentuk dalam perjalanan sejarah bagi setiap orang dengan tujuan konvergensi yang kurang lebih kompleks dan penekanan elemen-elemen dan asosiasi.' Karena itu, pemakaian ruang, klaim-klaim at as ruang, arsitektur bentuk-bentuk bangunan, dan konseptualisasi-konseptualisasi ruang, menyimpan imaginasi religius, yang dapat diterjemahkan (Metcalf, 1996: 21).

Untuk kasus Masjid Kyai Gede, arsitekt ural yang tampak tidak hanya mempertimbangkan budaya lokal (Kalimantan), melainkan juga adanya pertautan sejarah dengan asal sang pembangun masjid, Demak. Karena itu, model bangunan Masjid Kyai Gede sangat mirip dengan Masjid Agung Demak. Mengapa Kyai Gede meniru Masjid Demak? 
Pilihan model Masjid Demak yang diambil oleh Kyai Gede ini didasari dua alasan pokok. Pertama, Kyai Gede ingin menunjukkan bahwa dirinya mempunyai hubungan yang erat dengan para penyebar Islam (baca: walisongo) dan penguasa Kesultanan Islam Demak. Kedua, menurut peneliti Belanda, Masjid Demak merupakan titik pusat kehidupan masyarakat Islam pada masa awal. Sebagai tempat resmi yang pertama untuk salât al-Jum'ah, Masjid itu menjadi simbol masuknya Pulau Jawa dalam Dâr al-Islâm, rumah Islam. Penggulingan kraton Majapahit menjadi simbol kemenangan akhir gerakan jihad at au perang suci terhadap raja kafir terakhir, atau dengan kata lain, kemenangan rohani Islam ortodoks terhadap sisa-sisa pantheisme HinduBudha. Aliran mistik yang menyamakan Tuhan dengan semua kekuatan alam mulai saat itu secara resmi dilarang (Stokhof dan Kaptein, 1990: 130). Selain itu, bentuk arsitektur Masjid Demak merupakan prototipe bagi arsitektur masjid yang dibangun pada masa sesudahnya baik yang sifatnya masih tradisional maupun masjid-masjid dengan corak modern dengan penampilan bentuk atap tumpang (bumbung bertenggek) yang lebih dominan. Bentuk atap tumpang (tiga) sebenarnya tidaklah lazim digunakan pada bangunan- bangunan yang bercirikan seni Islam sebagaimana yang bisa dijumpai di negara-negara yang juga mayoritas penduduknya beragama Islam seperti Arab Saudi, Turki, Iran, Mesir, Maroko, dan Siria, dimana kubah menjadi pilihan utama sebagai penutup ruang utama bangunan masjid. Di sinilah letak keunikan dari masjid Demak yang pada akhirnya menjadi corak arsitektur masjid Nusantara. Walaupun dilingkupi oleh suasana "keramat", masjid Demak adalah produk sejarah yang menyimpan nilai-nilai filosofi tinggi yang kerap menjadi kajian para ilmuwan dari berbagai disiplin ilmu (Ashadi, 2002).

Sebagai gambaran, dilihat dari segi arsitekturalnya, bangunan Masjid Demak masih menampakkan gaya Hindu, tetapi telah dimodifikasi dengan warna Islam. Menurut sebuah cerita, masjid ini dibangun oleh walisongo. Empat buah saka guru di bagian tengah konon dibuat oleh empat orang wali; saka guru sebelah timur laut dibangun oleh Sunan Kalijaga (akhir abad ke-14pertengahan abad ke-15); saka guru sebelah barat laut dibangun oleh Sunan Bonang (1465-1525); saka guru sebelah tenggara dibangunan oleh Sunan Ampel (1401-1481); dan saka guru sebelah barat daya dibangun oleh Sunan Gunung Jati (1448-1570). Saka guru yang dibangun oleh Sunan Kalijaga disebut saka tatal (tiang yang dibuat dari pecahan kayu-kayu sisa). Masjid ini beratap tumpang dengan tiga susun dan memiliki tempat salat wanita yang terpisah dari tempat salat laki-laki oleh sebuah koridor yang sempit. Atapnya bersusun tiga yang terbuat dari kayu jati menggambarkan trilogi Islam: Islâm, 
îmân, dan ihsân (Saksono, 1995; Noer, 2002, IV: 329; Ashadi, 2002; Simon, 2006: 82-88). Berdasarkan gambaran ini, dapat dipahami alasan pola-pola arsitektural Masjid Kyai Gede mengikuti pola-pola Masjid Demak.

Sepintas dari bentuk atap dan keseluruhan bangunan, Masjid Kyai Gede memang mirip dengan pola-pola Masjid Demak, meski tidak sama persis. Perbedaan dengan Masjid Demak adalah bahwa masjid ini berupa bangunan panggung, berdiri di atas ketinggian kurang lebih 1,5 meter di atas permukaan tanah. Terdapat tangga dari kayu yang akan mengantar pengunjung masuk ke dalam masjid yang lantai dan dindingya seluruhnya terbuat dari kayu. Dengan luas masjid $16 \mathrm{~m}$ x16 m (256 m²), masjid kayu ini juga memiliki jam kayu yang bentuknya seperti tugu sebagai jam penunjuk waktu salat. Keunikan arsitektur masjid ini dapat pula dilihat dari desain interiornya. Terdapat 36 tiang yang terdiri dari 3 jenis untuk menyangga bangunan tanpa paku. Jenis tiang yang pertama adalah tiang utama (saka guru) berjumlah 4 buah dan terdapat tepat di tengah ruangan. Selain tiang dalam bangunan utama terdapat mihrab dan mimbar. Berbentuk segi-delapan dan berhiaskan motif sulur dan spiral; tiang utama tersebut berdiri di atas umpak kayu yang diukir serupa kelopak bunga teratai. Tiang lainnya berjumlah 12 yang tidak berukir dengan letak mengelilingi tiang utama. Selain itu, ada lagi 20 tiang berbentuk bulat yang fungsinya penyangga dinding. Ukurannya lebih kecil dari tiang yang berjumlah 12 dan letaknya menempel pada dinding bagian dalam masjid.

Bentuk limasan merupakan bentuk atap yang memiliki sudut berjumlah 5 yang menggambarkan 5 rukun Islam yaitu syahadat, salat, puasa, zakat dan haji yang menjadi hal wajib bagi yang mampu. Selain itu bisa di artikan 5 sudut ini adalah jumlah salat wajib yang harus dilaksanakan oleh umat muslim. Pintu masjid ini memiliki 5 buah yang bisa di artikan sama dengan limasan tadi. Pada esesnsinya pintu adalah jalan masuk, begitu pula maksud dari 5 pintu di masjid Kyai Gede ini adalah pintu yang akan membawa umat manusia pada kedamaian.

Selain ke-36 tiang, mihrab dan mimbar, di dalam Masjid Kyai Gede terdapat pula sebuah bedug dengan panjang $161 \mathrm{~cm}$ dan lebar $58 \mathrm{~cm}$ diletakkan di dalam masjid. Konon bedug ini adalah pemberian Kerajaan Demak (alKumayi, 2011). Bedug ini berfungsi sebagai pemberitahuan masuknya waktu salat. Menurut Amen Budiman (1979:40), asal-usul dari bedug yang diletakkan di serambi-serambi masjid Jawa, merupakan pengaruh dari arsitektur Cina, dimana bedug diletakkan tergant ung di serambi kelenteng (Budiman, 1979: 40; al-Qurthuby, 2003). Melalui bedug ini, Kyai Gede berperan besar dalam 
mentransformasikan budaya Cina via Jawa ke dalam masyarakat Muslim pedalaman Kalimantan Tengah. Uniknya, mereka tidak pernah mempersoalkan asal-usul bedug, dan bahkan menganggapnya bagian integral dari masjid itu sendiri.

Sebagaimana Masjid Demak, Masjid Kyai Gede juga menggunakan atap limas bersusun tiga yang berbentuk segitiga sama kaki. Atap limas ini berbeda dengan umumnya atap masjid di Timur Tengah yang lebih terbiasa dengan bentuk kubah. Ternyata model atap limas bersusun tiga ini mempunyai makna, yaitu bahwa seorang beriman perlu menapaki tiga tingkatan penting dalam keberagamaannya: Islâm, îmân, dan ihsân. Trilogi ini merujuk sebuah hadis yang menuturkan dialog antara Nabi Muhammad dan Malaikat Jibril yang menyamar sebagai seorang laki-laki berpakaian putih-putih.

"Jibril datang kepada Nabi s.a.w., dalam rupa seorang laki-laki, kemudian ia berkata, "Beritahu aku, wahai Muhammad, tentang Islâm?" Beliau menjawab, "Islâm berarti bahwa engkau hendaknya bersaksi bahwa tiada Tuhan selain Allah dan Muhammad ut usan Allah, engkau hendaknya mendirikan shalat, menunaikan zakat, puasa selama bulan Ramadan, dan melaksanakan ibadah haji ke Baitullah jika engkau mampu." Orang itu berkata, "Engkau benar." Kami terkejut at as pertanyaannya dan kemudian menyatakan bahwa beliau mengatakan hal yang benar. Ia berkata, "Beritahu aku tentang îmân?" Beliau menjawab, "Iman berarti bahwa engkau beriman kepada Allah, malaikatmalaikat-Nya, kitab-kitab-Nya, rasul-rasul-Nya, dan atas takdir, takdir baik maupun buruk." Setelah ia mengatakan bahwa beliau benar, kemudian ia berkata, "Beritahu aku tentang ihsân?" Beliau menjawab, "Ihsân berarti bahwa engkau hendaknya beribadah kepada Allah seolah-olah engkau melihat-Nya, dan jika engkau tidak bisa melihat-Nya, bahwa ketahuilah bahwa sesungguhnya Dia melihatmu" (Qusyairî, tth: 189).

Masing-masing unsur dalam trilogi tersebut akan membentuk tiga sendi: islâm membentuk sendi ritual (rukun Islam, syariat); îmân membentuk sendi teologis (rukun iman, sistem kepercayaan); dan ihsân membentuk sendi etika/ tasawuf. Tentu saja, setiap pemeluk Islam mengetahui dengan pasti bahwa Islam (al-Islâm) tidak absah tanpa iman (al-îmân), dan iman tidak sempurna tanpa ihsân (al-ihsân). Sebaliknya, ihsân adalah mustahil tanpa iman, dan iman juga tidak mungkin tanpa inisial Islam. Menurut Nurcholish Madjid (1994: 463), pengertian antara ketiga istilah ini terkait satu dengan yang lain, bahkan tumpang tindih sehingga setiap satu dari ketiga istilah itu mengandung makna dua istilah lainnya. Dalam iman terdapat Islam dan ihsân, dalam Islam terdapat iman dan ihsân, dan dalam ihsân terdapat iman dan Islam. Dari sudut pengertian 
inilah kita melihat iman, Islam dan ihsân sebagai trilogi ajaran Ilahi, yang penjabarannya dapat diskema di bawah.

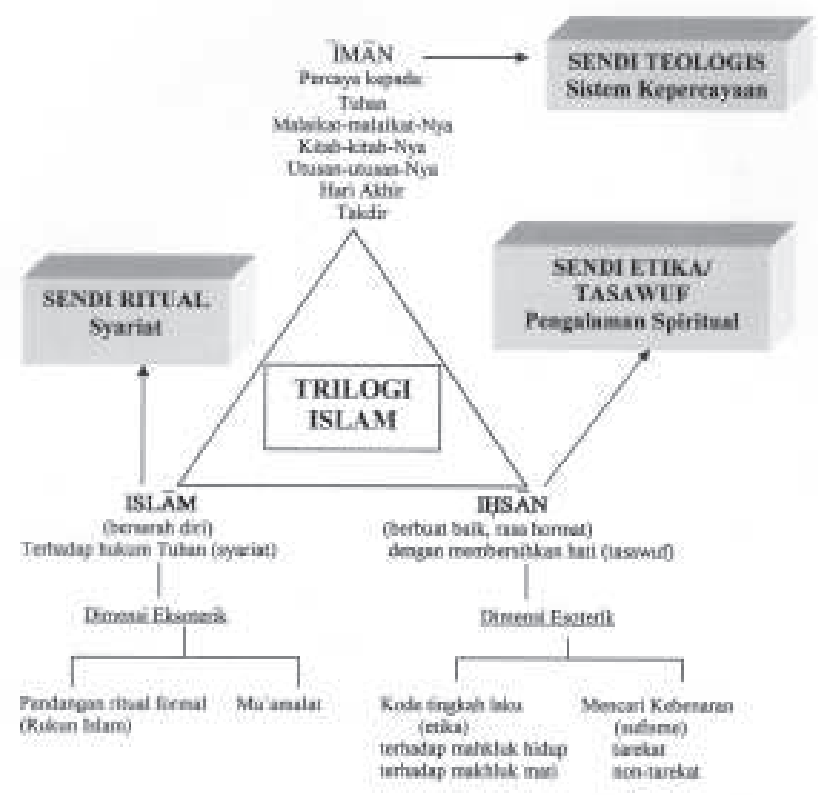

Ketika kita fokus pada atap limas ketiga Masjid Kyai Gede, yakni ihsân, memberikan pesan kepada umat Islam untuk merealisasikan ihsân dalam kehidupan sehari-hari atau selalu berbuat ihsân. Ihsân bermakna keindahan, kebaikan, dan moral sekaligus. Memiliki sifat ihsân berarti memiliki sifat kedermawanan dan cinta serta hidup dalam keadaan damai di jiwa, tempat lokus Tuhan berada (Nasr, 2002: 235). Menghiasi jiwa dengan keindahan (ihsân) melalui amal-amal spiritual berarti merealisasikan keindahan jiwa yang asal dan mengembalikan jiwa pada kondisi primordialnya, yaitu "bentuk yang seindahindahnya." Mencapai dan melakukan ihsân juga berarti memenuhi panggilan keindahan jiwa seseorang kepada si Pencipta, yang dalam al-Quran disebut sebagai Pencipta Yang Paling Baik dan Paling Bagus (QS. al-Mu'minûn [23]: 14); dan kepada Si Pemilik Nama-nama yang paling indah (QS. al-A'raf [7]: 180). Bahkan, ayat al-Quran yang terkenal, apakah ada balasan kebaikan selain kebaikan pula (ihsân) (QS. al-Rahmân [55]: 60) dapat juga dimengerti dengan makna, "Apakah ada balasan keindahan selain keindahan"; "apakah ada balasan bagi jiwa yang diperindah melalui ihsân selain Keindahan Yang Maha Esa?" (Nasr, 2002: 235).

Tujuan kehidupan manusia adalah memperindah jiwa melalui kebaikan dan moral dan membuatnya sebagai persembahan yang berharga kepada Tuhan, 
Yang Maha Indah. Mereka yang memiliki ihsân berpikir melalui ihsân dan bertindak serta berbuat dengan ihsân. Pikiran mereka didasarkan pada kebenaran yang aura dan cahayanya adalah keindahan, tindakan mereka selalu didasarkan pada ihsân, yaitu kebaikan-kebaikan, dan apa yang mereka buat mencerminkan keindahan dari benda "yang diukir Tuhan pada wajahnya" serta keindahan jiwa seorang pemahat. Memiliki ihsân berarti terbuka untuk menerima Kasih Sayang dan Kemurahan Tuhan dan menjadi penyayang atau pengasih kepada orang lain. Ihsân adalah mencintai Tuhan dan mencintai makhluk-Nya karena Tuhan. Ihsân adalah kedamaian dalam jiwa seseorang, yaitu dalam kondisi keseimbangan dan harmonis dengan dunia, di dalam dan di luar. Dan ihsân adalah menyelam dalam keindahan pada semua level manifestasinya, keindahan yang membebaskan kita dari batasan-batasan eksistensi keduniawian dan yang akhirnya akan menenggelamkan kita ke dalam samudra Ketidakterbatasan Tuhan (Nasr, 2002: 236).

\section{Dimensi Sakral-Magis}

Dimensi lain dari Masjid Kyai Gede adalah adanya unsur-unsur sakralmagis yang menyebabkan masjid ini dianggap mempunyai keajaibankeajaiban. Jika merujuk Syam (2005: 117-118), masjid menjadi sakral karena yang mendirikan masjid itu adalah orang yang dijadikan oleh Allah sebagai hamba yang terpilih. Hal yang sama terjadi pada Masjid Kyai Gede, di mana pendiri masjid tersebut adalah seorang ulama terkemuka dan dihormati, Kyai Gede. Umat Islam - khususnya masyarakat Muslim Kotawaringin Barat dan Kalimantan pada umumnya - masjid ini hingga sekarang diyakini memiliki kesakralan dibanding masjid-masjid lainnya. Oleh karena itu, banyak peziarah yang datang ke masjid ini, tidak hanya sekedar ingin melakukan salat di masjid tersebut, akan tetapi ingin membuktikan kebenaran tentang "kehebatan" bangunan masjid tersebut. Apalagi hingga usianya yang ratusan tahun tersebut, masjid ini tetap berdiri kokoh dan tidak pernah kebanjiran.

Unsur-unsur magis Kyai Gede terlihat dari kisah-kisah kedatangannya ke Kotawaringin. Siapakah sebenarnya Kyai Gede, hingga saat ini nama aslinya tidak diketahui dengan pasti. Sebuah sumber menyebutkan bahwa ia adalah salah satu murid Sunan Giri. Ia diperintahkan oleh Sunan Giri untuk menyebarkan Islam di Kalimantan dan tiba pada tahun 1591 (http://www.indonesia.travel/ ) .

Menurut seorang antropolog Belanda, J. Mallinckrodt (1990: 30), yang mengacu pada Hikayat Kyai Gede, Kyai Gede berasal dari Majapahit dan terpaksa pergi dari sana karena sengketa agama. Ia berada di Kotawaringin jauh 
sebelum Pangeran Anta Kasoema tiba, dan ia sekaligus sebagai representasi dari orang Melayu pertama di tengah-tengah komunitas Dayak. Mallinckrodt menambahkan, Kyai Gede adalah orang pertama yang membawa Islam ke daerah itu, yang menjadikannya dihormati oleh penduduk setempat. Menurut sumber lain yang ditulis oleh Ismail (1984: 21) menyebutkan bahwa Kyai Gede ini semula adalah salah seorang pembesar dan panglima Kerajaan Demak, masa pemerintahan Adipati Unus. Tatkala Adipati Unus menunjuk Kyai Gede memimpin pasukannya menyerang Jipang yang kebetulan hari itu adalah hari Jumat, Kyai Gede mengajukan usul agar keberangkatannya ditunda dulu, karena menurut firasatnya jika berangkat menyerang pada hari tersebut akan kalah. Adipati Unus tidak setuju, dan tetap memerintahkan menyerang, tetapi kalah. Kyai Gede dianggap gagal, dan konsekuensinya ia dipecat. Karena merasa frustrasi ia memutuskan meninggalkan Demak dan mengembara ke kesultanan Banjar dan kemudian ke Kotawaringin.

Sumber-sumber lokal itu menut urkan proses perjalanan Kyai Gede. Ia Kyai Gede ditempatkan dirakit dan didorong ke laut, kemudian seekor ikan menarik rakitnya sampai Kuala Kotawaringin. Di kuala sungai ini ia berencana akan menetap, tetapi dihalangi oleh penduduk setempat, dengan melemparinya terus-menerus dengan kotoran. Kyai Gede menjadi penasaran dan mencari pelaku pelemparan kotoran tersebut dengan cara bertapa (semedi, samadhi). Ia menemukan pelakunya, yaitu Raja Jin. Raja tersebut menyuruh Kyai Gede pergi dari muara tersebut dan pergi ke udik (hulu sungai). Raja Jin menyarankan kepada Kyai Gede, bahwa jika bertemu orang harus kembali ke hilir sampai tersangkut di pinggir sungai dan di situlah ia harus menetap. Kyai Gede mengikuti nasihat Raja Jin dan bertemu untuk pertama kalinya dengan orang-orang yang berada didekat sungai tersebut, yang sekarang dikenal sebagai Tanjung Baringan (Ismail, 1984: 21; Mallinckrodt, 1990: 30; al-Kumayi, 2008: 22). Orang-orang di sini menyebutnya "mamak", nama yang sampai sekarang melekat untuk menyebut etnis Dayak, penduduk asli setempat. Kyai Gede memperkenalkan diri sebagai "orang berniaga", kemudian lebih dikenal sebagai "Dayak Baniaga" nama yang sampai sekarang masih digunakan orang-orang Melayu.

Karena bertemu dengan orang-orang itu, Kyai Gede kembali menelusuri sungai ke hilir seperti yang dinasihatkan Raja Jin dan sampai di Tanjung Pangkalan Batu di mana rakitnya tersangkut. Ia segera bertemu dangan beberapa kepala dan minta izin menetap di sana. Ia diizinkan asal dengan syarat ketika mereka membawa upeti ke Sultan Banjar mereka terlebih dulu meminta pertimbangan Sultan. Hal ini didasarkan pada fakta bahwa wilayah mereka 
masuk dalam wilayah kekuasaan Kesultanan Banjar. Kyai Gede menyanggupi, dan ia diberi tempat tinggal di sana dan menamakan tempat tersebut Kotawaringin karena di sana terdapat dua pohon beringin besar, dan salah satunya sampai sekarang masih hidup. Dan Kyai Gede mempunyai kesempatan untuk mendakwahkan Islam kepada masyarakat setempat, dan untuk mempersatukan umat Islam, ia mendirikan sebuah masjid, yang dinamai sesuai dengan namanya (Ismail, 1984: 21-23; Mallinckrodt, 1990: 31-32; al-Kumayi, 2008: 22-23).

Setelah kematiannya, makam Kyai Gede dikeramatkan oleh Muslim setempat, dan bahkan memposisikannya sebagai wali Allah. Karena posisi ini, para peziarah ber-wasîlah kepada Kyai Gede untuk berbagai tujuan. Dalam alam pemikiran mereka, waliyullâh tersebut mempunyai kelebihan-kelebihan khusus, dan tanda-tanda kewalian itu sudah bisa disaksikan ketika ia hidup.

Merujuk Bambang Pranowo (2009), kepercayaan kepada orang-orang suci (wali) merupakan bagian yang tidak terpisahkan dari kehidupan Muslim Indonesia. Ungkapan ini membenarkan pernyataan Gilsenan yang menyatakan bahwa "Ketika pintu kenabian sudah ditutup, maka pintu kewalian pun terbuka" (Gilsenan, 1973: 11). Pernyataan ini benar, jika dilihat dari fenomena sosialbudaya di mana "penghormatan dan pemujaan" terhadap wali menjadi sebuah ritual yang berlaku sejak lama di kalangan dunia Islam, termasuk di Indonesia (Koentjaraningrat, 2002: 329-331).

Dalam konteks sosio-kultural istilah 'wali' adalah orang yang dianggap dekat dengan Tuhan, dan diantara bukti kedekatannya itu dapat diketahui dari sikap dan perilakunya yang tampil sebagai orang yang saleh, tekun beribadah, sikapnya arif dan banyak membimbing, sering kali berbuat hal-hal yang luar biasa di mata masyarakat (kharîq al-adat) karena karamahnya, dan doa-doanya sering kali terkabulkan dalam waktu yang relatif singkat. Oleh karenanya orang yang diyakini masyarakat sebagai wali, selalu dihormati, disegani dan ditaati. Karena kedekatannya dengan Tuhan seorang wali sering dijadikan wasîlah (perantara, rekomendator) dalam berhubungan dengan Tuhan, baik dalam bentuk doa atau ibadah lain. Bahkan setelah ia meninggal tidak jarang kuburannya dianggap sebagai tempat keramat yang banyak diziarahi orang terutama orang awam dengan berbagai macam tujuan dan cara berziarah, mulai dari yang benar sampai yang menyimpang dari batasan-batasan dan adab berziarah (Hasan, 2005: 281).

\section{Penjaga Mazhab Ahlu as-Sunnah wa Al-Jamâ'ah}

Kehadiran Kyai Gede dan masjidnya tidak diragukan lagi adalah penjaga Ahlu as-Sunnah wa al-Jamâ'ah, maksudnya, golongan orang-orang yang ibadah 
dan tingkah lakunya selalu berdasarkan pada al-Qur'an dan hadis, sementara pengambilan hukum Islamnya mengikuti mayoritas ahli fikih (sebagian besar ulama ahli hukum Islam). Dalam menjalankan ritual agamanya, kaum Sunni (sebutan kaum yang mengikuti faham Ahlu as-Sunnah wa al-Jamâ'ah) menganut satu dari empat mazhab: Hanafî, Mâlikî, Syafi‘ ‘̂, dan Hanbalî, serta mengikuti Abû Hasan al-Asy'arî dan Imâm al-Matûridî dalam bidang akidah, keduanya dipandang sebagai ulama besar yang telah berjasa mengibarkan bendera Ahlu as-Sunnah wa al-Jamâ'ah dan menyatakan diri keluar dari faham Mu'tazilah (Fattah, 2006: 7-8; Hasan, 2005: 3-57). Karena itu, faham-faham baru tidak mudah masuk ke wilayah Kotawaringin Lama, karena keberadaan Masjid Kyai Gede yang tetap eksis dengan Ahlu as-Sunnah wa al-Jamâ'ah.

Kuatnya pengaruh Ahlu as-Sunnah wa al-Jamâ'ah di masyarakat Kotawaringin tidak bisa dilepaskan dari mazhab yang dianut oleh Kyai Gede sendiri. Sebagai murid sunan, dapat dipastikan bahwa mazhabnya adalah Ahlu as-Sunnah wa al-Jamâ'ah. Menurut Saksono (1995: 103), para wali (baca: walisongo) itu sejiwa, yaitu jiwa Islam; seideologi dan sealiran, yaitu tasawuf dan mistik; dan sejalan pikiran, yaitu jalan pikiran Ahlu as-Sunnah wa alJamâ'ah. Mazhab ini, di samping mengutamakan soal-soal batin, seperti tasawuf, mistik, dan akhlak, juga tidak melalaikan soal-soal lahir seperti syariat (Saksono, 1995: 168). Karena itu, ketika penulis pernah bertanya kepada masyarakat setempat mengenai mazhab yang mereka anut, maka secara tegas mereka menjawab sebagai penjaga Ahlu as-Sunnah wa al-Jamâ'ah, karena mengikuti Kyai Gede dan sekaligus penjaga mazhab tersebut.

\section{E. Simpulan}

Berdasarkan uraian di atas, dapat ditarik simpulan sebagai berikut. Pertama, Masjid Kyai Gede menjadi bukti sejarah kuatnya pengaruh Masjid Demak terhadap model arsitektur bangunan masjid di pedalaman Kalimantan Tengah ini. Meskipun sedikit ada adaptasi dengan lingkungan lokal, namun orientasi dan spirit ke-Demak-an itu sedemikian kuat, sehingga sang pendiri, Kyai Gede berusaha sedekat mungkin dengan Masjid Demak. Kedua, Masjid Kyai Gede tidak hanya bangunan bersejarah, tetapi ia juga dianggap sebagai sebuah tempat yang sakral dan penuh daya magis. Para peziarah akan merasakan pengalaman spiritual luar biasa ketika salat di masjid ini. Dan ketiga, ini bagian yang paling penting, bahwa Masjid Kyai berperan besar dalam mengenalkan mazhab Ahlu as-Sunnah wa al-Jamâ'ah, dan masyarakat lokal sedemikian teguh mempertahankannya, dan bahkan mereka adalah penjaga teguh mazhab ini. 


\section{Daftar Pustaka}

Ashadi. 2002. "Masjid Agung Demak sebagai Protipe Masjid Nusantara: Filosofi Arsitektur", Jurnal Arsitektur-Nalars, Volume I, Nomor Perdana, Januari.

Azra, Azyumardi. 2002. "Peradaban Islam" dalam Ensiklopedi Tematis Dunia Islam, Jil. IV. Jakarta: PT. Ichtiar Baru Van Hoeve.

Bennyarmansyah. 2011. "Semiotika Desain Masjid Salman ITB". Artikel diakses dari http://bennyarmansyah.wordpress.com/

Budiman, Amen. 1979. Masyarakat Islam Tionghoa di Indonesia. Semarang; Penerbit Tanjungsari.

Chittick, William. 2006. "Foreword" untuk Rusmir Mahmutæhajiæ The Mosque:

The Heart of Submission. New York: Fardham University Press.

Djaya, Sulaiman. 2014. "Simbol Estetik Masjid". http://sulaimandjaya. blogspot.com/(akses 28 Februari 2014)

Faruqi, Ismail R dan Lois Lamya. 1986. The Cultural Atlas of Islam. New York: Macmillan Publishing Company.

Fattah, Munawir Abdul. 2006. Tradisi Orang-orang NU. Yogyakarta: Pustaka Pesantren.

Gilsenan, Michael. 1973. Saint and Sufi in Modern Egypt: An Essay in the Sociology of Religion. Oxford: Oxford University Press.

Handinoto dan Samuel Hartono. 2007. "Pengaruh Pertukangan Cina pada Bangunan Mesjid Kuno di Jawa Abad 15-16”. Jurnal Dimensi Teknik Arsitektur, Vol. 35, No. 1, Juli.

Hasan, Muhammad Tholhah. 2005. Ahlussunnah wal-Jama'ah Dalam Persepsi dan Tradisi NU. Jakarta: Lantabora Press.

Iskandar, M. Syaom Barliana. 2004. "Tradisionalis dan Modernitas Tipologi Arsitektur Masjid”. Jurnal Dimensi Teknik Arsitektur, Vol.32, No. 2, Desember.

Ismail, M. Sahloel. 1984. Kotawaringin menurut Cerita Rakyat. Naskah tidak diterbitkan. Palangka Raya (Kalimantan Tengah).

Kahera, Akel Ismail. 2002. Deconstructing The American Mosque: Space, Gender, and Aesthetics. Austin: University of Texas Press.

Koentjaraningrat. 2002. Manusia dan Kebudayaan di Indonesia. Jakarta: Djambatan.

Kumayi, Sulaiman. 2008. Ma'rifatullah: Pesan-pesan Sufistik Panglima Utar. Semarang: Walisongo Press. 
Kumayi, Sulaiman. 2011. Islam Bubuhan Kumai: Perspektif Varian Awam, Nahu, dan Hakekat. Jakarta: Kementerian Agama RI.

Kuntowijoyo. 2003. "Masjid atau Pasar: Akar Ketegangan Budaya di Masa Pembangunan." Makalah dalam Seminar KPFI IAIN Sunan Kalijaga Yogyakarta, 17-19 Oktober.

Machrus. 2008. Simbol-Simbol Sosial Kebudayaan Jawa, Hindu Dan Islam Yang Direpresentasikan Dalam Artefak Masjid Agung Surakarta: Studi Semiotika Komunikasi Tentang Simbol-Simbol Sosial Kebudayaan Jawa, Hindu Dan Islam Yang Direpresentasikan Dalam Artefak Masjid Agung Surakarta. Tesis Magister Pascasarjana Universitas Sebelas Maret. Madjid, Nurcholish. 1994. "Islam, Iman dan Ihsan sebagai Trilogi Ajaran Ilahi" dalam Budhy Munawar-Rachman (ed.), Kontekstualisasi Doktrin Islam Dalam Sejarah. Jakarta: Paramadina.

Mahmutæhajiæ, Rusmir. 2006. The Mosque: The Heart of Submission. New York: Fardham University Press.

Mallinckrodt, J.. 1990. "Beberapa Hal Mengenai Kebiasaan di Istana Kotawaringin" dalam Ny. Retno Inten Maulani, Beberapa Catatan Sekitar Kerajaan Kotawaringin oleh Beberapa Ahli Sejarah Anthropologi. Balik Papan: tp.

Metcalf, Barbara Daly. 1996. Making Muslim Space in North America and Europe. Berkeley and Los Angeles: University of California Press.

Nahlawi, Abdurrahman. 1995. Pendidikan Islam di Rumah Sekolah dan Masyarakat Jakarta: Gema Insani Press.

Nasr, Seyyed Hossein. 2002. The Heart of Islam: Enduring Values for Humanity. New York: HarperSanFrancisco.

Noer, Kautsar Azhari. 2002. “Arsitektur” dalam Ensiklopedi Tematis Dunia Islam, Jil. IV. Jakarta: PT. Ichtiar Baru Van Hoeve.

Norman, A Donald. 2004. Emotional Design. New York: A Member of Perseus Books Group.

Pijper, G.F. 1985. Beberapa Studi Tentang Sejarah Islam di Indonesia 19001950, terj. Tujimah, Jakarta: tp.

Pranowo, M. Bambang. 2009. Memahami Islam Jawa. Jakarta: Pustaka Alvabet. Qurtuby, Sumanto. 2003. Arus Cina-Islam-Jawa. Yogyakarta: Inspeal Ahimsakarya Press.

Qusyairî, Abû al-Qâsim, tth. al-Risâlah al-Qusyairiyah. Beirut: Dâr al-Khair. 
Saksono, Widji. 1995. Mengislamkan Tanah Jawa: Telaah atas Metode Dakwah Walisongo. Bandung: Mizan.

Simon, Hasanu. 2006. Misteri Syekh Siti Jenar: Peran Walisongo Dalam Mengislamkan Tanah Jawa. Yogyakarta: Pustaka Pelajar.

Suparlan, Parsudi. 1993. "Kata Pengantar" dalam Roland Robertson (ed.), Agama: Dalam Analisa dan Interpretasi Sosiologis, penerj. Drs. Achmad Fedyani Saifuddin, MA. Jakarta: PT. RajaGrafindo Persada.

Suparlan, Parsudi.1995. The Javanese in Suriname: Ethnicity in an Ethnically Plural Society. Tempe, Arizona: Arizona State University.

Syam, Nur. 2005a. Islam Pesisir. Yogyakarta: LKiS.

Stokhof, W.A.L. dan N.J.G. Kaptein (ed.). 1990. Beberapa Kajian Indonesia dan Islam. Jakarta: INIS.

Talmon-Heller, Daniella. 2007. Islamic Piety in Medieval Syria Mosques, Cemeteries and Sermons under the Zangids and Ayy"bids (1146-1260). Leiden-Boston: Brill. 